\title{
FOSSIL CLUES TO PALEOECOLOGY OF DEEP-SEA HYDROTHERMAL VENT FAUNA: SUMMARY OF RECENT FINDINGS
}

LUTZ*, Richard A., Institute of Marine and Coastal Sciences, Rutgers University, New Brunswick, NJ 08903 U.S.A.; HAYMON, Rachel M., Dept. of Geological Sciences, Marine Science Institute, University of California, Santa Barbara, CA 93106 U.S.A.

An abundant and unusual fauna is associated with deep-sea hydrothermal vents on the crest of the global mid-ocean ridge system. Precipitation of metal sulfides, silica, iron-oxyhydroxides and other minerals at these vents encrusts and replaces the remains of dead organisms to form fossils that may be preserved in the geologic record. For example, molds and casts of tubiculous polychaete and vestimentiferan worms are abundantly preserved in Recent hot spring deposits on the mid-ocean ridge crest, and similar worm molds also have been found in Tethys ophiolite sulfide mineral deposits of mid-Cretaceous age. The aragonitic and calcareous shells and tests of other vent species are also good candidates for fossilization by encrustation and replacement of their carbonate constituents with hydrothermal minerals.

Recent and ongoing studies of the ecology and mineralization of vent organisms at active hot spring sites on the mid-ocean ridge in the eastern Pacific provide knowledge needed for gleaning paleoecological information from fossiliferous marine hydrothermal deposits in the geologic record. At modern vents, intact larval shells (prodissoconchs or protoconchs) are present on the surfaces of many juvenile molluscs. Preservation of these larval shells by hydrothermal mineralization may provide a powerful paleoecological tool for interpretation of the life history strategies of many sessile invertebrates associated with ancient submarine hydrothermal vents. Bacterial mats that grow on the outer surfaces of sulfide mineral structures have been preserved by silica deposition in inactive deposits on the East Pacific Rise (EPR) axis at $9^{\circ} 27^{\prime} \mathrm{N}$. Studies of the ecology and growth history of this bacterial species at active vents are in progress.

Preservation of ridge crest vent fauna within volcanic rock units can occur when lava erupts on the ridge crest near hydrothermal vent communities. Along the axis of the EPR at $9^{\circ} 50.6^{\circ} \mathrm{N}$, vent mussels and vestimentiferan worms were found partially buried by lava flows and volcanic collapse rubble. Animals trapped beneath eruption-associated rubble may be coated or replaced by hydrothermal minerals precipitating from fluids circulating in the cooling rocks. In addition, worm-tube molds were created at the EPR $9^{\circ} 50.6^{\prime} \mathrm{N}$ site where lava quenched around living vestimentiferans (analogous to the formation of tree-molds in Hawaiian lava flows). These lava molds contained pyritized remnants of the chitinous tubes of the vestimentiferans. 